\title{
Job Creation and Decent Work in Oyo State Nigeria
}

\section{Oluwakemi Bolaji Okuwa}

Nigerian Institute of Social and Economic Research, Ojoo, Ibadan, Nigeria

Email:kemiokuwa@yahoo.co.uk

How to cite this paper: Okuwa, O. B. (2020). Job Creation and Decent Work in Oyo State Nigeria. Modern Economy, 11, 1752-1770.

https://doi.org/10.4236/me.2020.1111120

Received: September 17, 2020

Accepted: November 14, 2020

Published: November 17, 2020

Copyright (c) 2020 by author(s) and Scientific Research Publishing Inc. This work is licensed under the Creative Commons Attribution International License (CC BY 4.0).

http://creativecommons.org/licenses/by/4.0/

\begin{abstract}
Employment generation is the single most-critical economic challenge facing the world today. Job creation is on the agenda of many governments and Sustainable Development Goals (SDG) emphasises productive employment and decent work for all. ${ }^{1}$ The critical question to ask is: How decent are the jobs created through Social Investment Program (SIP) in addressing graduate unemployment in Nigeria? It is against this backdrop that this study sets out to examine how jobs created through the N-Power programme in Oyo State promote decent work. Primary data, using a structured questionnaire and focused group discussions were used to address the questions based on the four dimensions of decent work furnished by the International Labour Organisation (ILO). The study adopted a multi-stage random sampling technique and administered 376 questionnaires to N-Power program beneficiaries; this was supported by two-focused group discussion. Descriptive statistics and content analysis were used to analyse the data generated. Results show that the SIPs addressed the issue of unemployment but the job cannot be termed decent because of lack of job security, right of work and social dialogue. The study, therefore, recommends that the conditions of engaging graduates should be reviewed in terms of salary structure and period of engagement. There could be the inclusion of some basic rights at work during their engagement and the tenure should be increased from two to three years with the option of engaging some of the beneficiaries as full-term staff at the Federal and State level based on specific criteria that the beneficiaries will meet. Start-up capital/quality equipment should be given to those who prefer to be on their own as a young entrepreneur.
\end{abstract}

\section{Keywords}

Job Creation, Decent Work, Employment, N-Power

${ }^{1}$ The Buhari's administration pledged to create 3.5 million jobs over three years (2016-2018) and strived to actualise it through Social Investment Programmes (SIPs) in which N-power (job programme for unemployed graduates) is one. 


\section{Background}

Productive employment and decent work are key elements in achieving fair globalisation, poverty reduction and fostering equitable inclusive development. Access to decent work, therefore, is an antidote to social exclusion rights across the global economy. Decent work refers to the income component of productive employment regarding the condition of work such as the absence of coercion (no slavery, no child labour), equity at work (equity of conditions and opportunities for all workers), security at work (health, pensions, security against job loss), and dignity of work (Anker et al., 2003). It also means not working for more than 48 hours per week. Four identified indicators of decent work are employment creation, right at work, social dialogue and social protection (ILO, 2012). The International Labour Organisation (ILO, 2009a) defines productive employment as employment yielding sufficient returns permitting workers and their dependents a level of consumption above the poverty line. It has three important dimensions: remuneration, the stability of employment and working condition.

Over 200 million people are unemployed across the globe with young people faring poorly because enough jobs are not being created to absorb new entrants to the workforce. Tackling this high unemployment rate, particularly among the youth, is a pressing challenge in developed and developing countries. Underemployment, casual and informal employments are predominant in many developing countries including Nigeria. Underemployment refers to situations where productivity and earnings are so low that a worker cannot make a decent living in a normal job and has to work very long hours to survive. Other connotations of underemployment are that the job does not make use of the workers' skills, education and experience. It is also a situation where the time workers work less than they would like (part-time work instead of full-time work). Vulnerability refers to work with highly fluctuating and uncertain returns, and without a stable and secure relationship between employer and employee. Vulnerability is an important aspect of unproductive labour. It is a typical characteristic of informal sector jobs (Szirmai, Gebreejessetal, Guadagno, \& Verspagen, 2013).

Provision of better job opportunities ranks among the top development priorities of the United Nations (UN) because it concerns people of all ages in all countries. Employment generation, therefore, has emerged as the single most critical economic challenge facing the world today. This is why job creation is on the agenda of many governments worldwide and Goal 8 of Sustainable Development Goals (SDGs) emphasises productive employment and decent work for all. Job creation, especially among the youth, is one of the priorities of Buhari's administration as it pledged to create 3.5 million jobs over three years (2016-2018). Strategic framework and implementation plan for job creation and youth employment in Nigeria (2016-2018) was put in place by the Federal Government and this is being managed by Job Creation Unit (JCU) in the office of the 
vice-president which coordinates activities and interventions aimed at driving job creation across Nigeria. The role of JCU is to coordinate, facilitate and elevate promising growth strategies within specific clusters of economic activities to stimulate job creation. The framework focused on these four strategic sectors:

- Agribusiness and agro-allied industries.

- Construction.

- ICT and Digital Jobs

- Wholesale and retail trade.

The specific sectors are cluster-driven while micro, small and medium enterprises (MSMEs) serve as means of generating jobs in all the sectors. The job creation programmes of the Buhari administration are being achieved through Social Investment Programmes. These programmes are national home-grown school-feeding programme, N-power (job programme for unemployed graduates), Conditional Cash Transfer (CCT) and Government Enterprises Entrepreneurship Programmes (GEEP) for traders and market women. The question that comes to mind is how decent are these jobs. It is against this backdrop that this paper set out to examine how jobs created through $\mathrm{N}$-Power programme (N-Agro, N-Teach and N-Health) in Oyo State promote decent work using ILO indicators of decent work to address the issue of employment creation, right at work, social dialogue, social protection and security.

\section{Stylized Fact of Employment Situation in Oyo State}

Nigeria with an estimated population of over 170 million is endowed with enormous potentials in form of natural and human resources. The country has a GDP of $\$ 488$ billion, GDP per capita of $\$ 2688$ (National Bureau of Statistics, 2017) and maintained a GDP growth of about 6.8 per cent from 2010 to 2015. Notably, the greatest concern of the growth recorded in Nigeria is that it has not created sufficient productive employment to lift a large number of the population out of poverty (International Labour Organisation, 2013; Fine et al., 2012). Twenty-five per cent of the Nigerian labour force is unemployed or underemployed, casting a gloomy prognosis on the country's future. The depth of Nigeria's unemployment crisis is particularly evident amongst youths; this poses a great threat to the growth of the economy hence; Nigeria needs to create many more decent jobs as young people continue to join the workforce en masse over the next $8-10$ years.

The unemployment figure has been growing over the years despite numerous programmes at the federal and state levels to generate employment opportunity, especially for graduates. The trend of unemployment in Nigeria has shown that the rate remains high. According to the National Bureau of Statistics (NBS), the unemployment rate declined to 5.3 per cent in 1981 from 6.4 per cent in1980 in response to measures put in place. Decades after, the country's unemployment rate grew from 10.4 per cent in the last quarter of 2015 to 12.1 per cent in the first quarter of 2016. The number of employed people in Nigeria increased from 
61.8 million people to 68.2 million in the fourth quarter of 2014 which declined to 53.9 million in the first quarter of 2016. Notably, despite this decline, how productive and decent are these jobs, especially those created in the agribusiness/agro-allied sector through N-Power Programm. The economically active population or working-age population (persons within ages 15 - 64) increased from 105.02 million in Q4 2015 to 106.0 million in Q1 2016. These are the major challenges of the Nigerian economy and Oyo State in particular alongside the poor growth performance of the economy depicted by the rising incidences of poverty, massive and graduate unemployment, skyrocketing inflation, worsening balance of payments disequilibrium, monumental external debt burden, widening income disparity and growing fiscal imbalances.

Since crude oil became the mainstay of the Nigerian economy roughly 40 years ago, agriculture has ceased to take the centre stage in the national economic discourse. In the colonial and immediate post-colonial era Oyo State was at the forefront of agricultural development in Nigeria. This accounted for the establishment of almost 40 per cent of Nigeria's agricultural research institutes in the state. Over the years, shifts in the country's labour force from the agricultural sector to others, especially manufacturing and agro-processing, have characterised economic development. This is mostly due to the moderate growth of the agricultural sector occasioned by the use of improved seeds and planting materials, weed and pest management practices and mechanisation. According to NBS (National Bureau of Statistics, 2017), a person is regarded as employed if engaged in the production of goods and services, thereby contributing to the GDP in a legitimate manner, which is a component of the National Accounts and receives any form or amount of compensation for the activity. The economically-active or working-age population (15 - 64 years) in Nigeria increased from 109.44 million in the first quarter (Q1) to 111.1 million in Q3, 2017. The labour force population increased from 83.9 million in Q2, 2017, to 85.1 million in Q3, 2017. Oyo State is the fifth most populous state in Nigeria. Labour force statistics, at the end of Q3, 2017, revealed an increase in the labour force population from 3,792,840 in Q1 to 3,907,460 in Q3. During this period, workers in Oyo State who were on full-time employment and worked 40 hours/week decreased from 3,019,874 in Q1, 2017, to 3,007,593 in Q3, 2017. The unemployment rate at Q1, 2017, stood at 9.2 per cent and in Q3 at 13.9 per cent (National Bureau of Statistics, 2017) while underemployment was estimated at much higher levels.

\section{N-Power Programme in Oyo State}

$\mathrm{N}$-power programme is one of the job creation and empowerment initiatives of the Social Investment Programme of the Nigerian government that covers the 36 states of the federation. The N-Power Programme is providing economic and manpower development through employment creation, skills development and innovation transfer to youths between the ages of 18 and 35, N-power programme is the Federal Government's first step in diversifying into a knowledge 
economy. It works alongside the highlighted eight innovation hubs across the country to provide incubation and acceleration of the technology and creative industries. It is a "training to job" initiative that gets participants engaged in the market place. It has three focuses:

- N-Power Build.

- N-Power Knowledge.

- N-Power Volunteer Corps.

Though N-Power is not the country's first labour social intervention programme, it has a large coverage compared with SURE-P, introduced in February 2012. The N-Power scheme was established to bridge the gap between formal skills, as a result of the country's poor education system, and the vocational and entrepreneurial skills needed to make youths self-reliant (Ministry of Budget and National Planning (MBNP), 2017). In Oyo State, the N-power is domiciled in the Ministry of Women's Affairs, Community Development and Social Welfare with the Honorable Commissioner as the focal person assisted by a coordinator. The selection of graduates for the programme is on-line and transparent; it is one of the first empowerment programmes in the country for which the beneficiary does not need any "Godfather" or someone to influence the chance of being selected. Below is the comment of the coordinator of N-power in the state on the selection process:

"Selection process is on-line irrespective of your locality and state, it is the first empowerment program that selection is fair and transparent. You don't need any connection. People were rejected/disqualified based on age and mismatched of names and bank accounts".

\section{Literature Review}

There are five indicators in the literature that can be used to capture the working condition dimension of decent work. These are the absence of coercion (no slavery, no child labour), Equity at work (equity of conditions and opportunities for all workers), Security at Work (Health, Pension, Security against job loss), Dignity of work (not more than 48 hours a week) (Anker et al., 2003; Hoeven, 2012). Better job opportunities rank among the top four development priorities of the UN because it concerns people of all ages in all countries. Employment issues should be addressed using productive and decent work lens that does not focus on employment creation alone but also includes the perspectives of the principles and right to work, social protection and inclusion. Many studies on Nigeria's employment situation have been devoted to unemployment and its determinants and/or its impacts on economic growth (Adebayo \& Ogunrinola, 2006; Oladeji, 1994; Omotor \& Gbosi, 2006). Kareem (2015) investigates the impact of employment level on economic growth in Nigeria and concluded that there is a uni-directional relationship between employment and economic growth.

Paredes Gil et al. (2007) examined the local employment situation in a construction company in Santo Andre with some indicators of the four key compo- 
nents of decent work using a qualitative and quantitative approach. The result shows that decent work indicator reveals positive trends towards, and negative trends away, from decent work. Specifically, the study shows that employment conditions, social security and workers' right are being promoted and developed by different programmes and projects implemented by the local authority. However, not much attention has been given to the analysis of productive and decent employment that can drive sustainable development in Nigeria. The Nigerian economy has not supported employment generation, especially decent employment.

Haji (2007) provides a review of the youth employment situation and challenges in the East African (EA) countries. The study finds that youth employment problems are common and continue to pervade the EA economies, with a disproportionately large number of young women and men exposed to long-term unemployment or short-term work in the informal sector. As a result, several of them dropped out of the workforce or failed to enter successfully in the first place and became inactive. Socially-disintegrated youth are particularly affected, thereby perpetuating a vicious circle of poverty and social exclusion. The challenge, therefore, is to design integrated employment-generating macroeconomic policies that create decent opportunities for young women and men, who represent a majority of the population and in the labour force.

Lawrence et al. (2008) using documentary sources and case studies of four countries, analyse whether the concept of decent work is known and applied by local authorities in their policy definition and project implementation in the construction sector and related services. This shows that decent work remains a marginal concept that has not been widely applied at the international, national and local levels. The paper concludes that cities and municipalities are key actors in the generation of gross domestic product. Therefore, local authorities can catalyse the promotion of decent work that guarantees income, equity, security, and dignity to members of local communities. They can also be the arena for decent work, living conditions, social security and dialogue between members of civil society.

Thore \& Tarverdyan (2009) examine the deficiency of the four elements of ILO decent work indicators using data envelope analysis (DEA). The result shows that 27 out of 60 sampled countries are in the decent work frontiers (employment, rights, social protection, and social dialogue) whereas the remaining countries reveal conditions of decent work deficits. Ghai (2005) summarised the interrelationship between the four main components of decent work. The first important interdependency issue is how employment level impacts on social security systems and, if the level of paid employment in the formal sector is relatively low, this will increase the need for some types of social protection. Therefore, the financing of social security systems is influenced by the proportion of workers according to their work categories. Besides, the distribution of the labour force into different work categories also influences the modes of negotiation between workers unions and employers' associations. This affects workers' 
opportunities and limits their capacity to negotiate other issues such as their rights.

Fajana (2010) adopted an analytical methodology to review available literature and archival resources on decent work deficits in Nigeria. The study identified the following major decent work deficits in Nigeria: poverty arising from sustained unemployment, especially among youths, child labour and trafficking in persons, increased vulnerability of spouses and children of people living with HIV/AIDS, informal sector employees and albinos, inadequate social protection for people in old age and disability, issues with labour administration, and lack of capacity on the part of the constituents. The incidence of the global financial crisis aggravated the effects of the foregoing deficits. Policy gaps were identified after considering the mutual efforts of the government and the UN. Ayyagari, Demugucukunt \& Maksimovic (2011) examined the contribution of SME sectors to total employment, job creation and growth in 99 countries using descriptive analysis from cross-country database, and their findings show that small firms (firms with less than 100 employees) and matured firms (firms older than 10 years) have the largest shares of total employment and job creation, while larger firms and younger firms have higher productivity growth.

Brixiova et al. (2020) developed a model that showed that in the absence of assets that can serve as collateral and given other financial market imperfections, access to credit constraints SMEs growth and job creation. The model was then applied to firm-level data of 42 Sub-Saharan African countries over the period 2006 to 2009 to examine the impact of access to finance on job creation and employment growth. Findings from the study showed that SMEs with access to formal financing creates more jobs than those without access, with employment growing largest in firms having access to more affordable and larger loans. The study also revealed that the impact of access to finance on job creation is stronger for manufacturing firms than service-based firms. Using the recently proposed Psychology of Working Theory (PWT), Chen et al. (2020) examined the predictors and outcomes of decent work. The study used the model to compare samples of public and private employees in China from different economic and occupational backgrounds. The framework uses economic constraints as a predictor, job and life satisfaction as the outcome, and work volition, career adaptability and decent work as mediators. The results show that economic constraints had a negative relationship with work volition, which implies that limited economic resources constrain individuals' ability to make career-related decisions. The result showed a negative relationship between economic constraints and career adaptability implying that individuals with fewer resources are less adaptable in their working lives. The results further showed that individuals that can make their own career-related decisions and those that are more adaptable are better able to get decent work, while a positive relationship exists between decent work and job satisfaction.

Braganza et al. (2020) examined the tensions between SDG Goal 8 of promoting productive employment and the adoption of Artificial Intelligence (AI). The 
study used 232 survey results to test the effects of AI adoption on workers' psychological contract, engagement and trust. The findings showed that psychological contract had a significant positive effect on job engagement and trust, but with AI adoption, the positive effects of psychological contract fell significantly. The findings further showed that AI adoption creates a third type of psychological contract termed "alienation". While SDG 8 is supposed to strengthen relational contracts between an organization and its employees, the adoption of AI has the opposite effect, which is denigrated from the very nature of decent work.

Coulibaly \& Yogo (2020) examined the effects of financial outreach on the number of workers living below the poverty line and also analyzed whether this effect may occur through increasing investment, remittances, private credit and the number of rich workers who can provide decent job opportunities for the poor. Using a sample of 63 developing countries between 2004 and 2013, the study found that improving financial outreach through additional bank branches reduces the number of poor workers especially in developing countries hit by macroeconomic instability. The results further showed that this effect occurs mainly through expansion, while other channels substitute financial outreach in countries with low levels of financial development. Duffy et al. (2019) explored the link between decent work and physical and mental health in a sample of 497 employed adults with an annual household income of less than $\$ 50,000$. The findings of the study suggest that securing decent work promotes increased mental health primarily because work is meeting individual needs and may promote physical health partly by helping to meet survival needs.

\section{Theoretical and Conceptual Framework}

Several theories have been addressing employment/job creation over the years though classical economists always believe in the existence of full employment. Their view is characterised by consumer sovereignty; individual utility and profit maximisation, perfect competition and economic efficiency with very many "atomistic" producers and consumers, none of whom is large enough to influence prices or wages (Todaro, 1980). According to Keynes, full employment means the absence of involuntary unemployment. He assumes that, with a given organisation, equipment and technique, real wages and the volume of output (and hence of employment) are uniquely co-related, so that, in general, an increase in employment can only occur to the accompaniment of a decline in the rate of wages (Todaro, 1980). The neo-classical price incentive school of thought has occupied a prominent place in the debate about employment problems in developing countries. Their theory is based on the proposition that producers (firms and farms) are assumed to face a given set of relative factor prices (e.g. of capital and labour) and to utilise that combination of capital and labour which minimises the cost of producing a desired level of output. They further assume the capability of producing a given output with a variety of technological production processes, ranging from labour-intensive to capital-intensive methods 
(Todaro, 1980). The actual employment impact of removing factor price distortions will depend, however, on the degree to which labour can be substituted for capital in the production processes of various countries.

\section{Conceptual Framework}

Every country has its own goals and institutions that facilitate decent work but there are broad goals that are largely shared. Further, within the efforts to achieve decent work the flexibility of employment relationship is part of a much wider balance as well as incorporating both quantity and quality of work in which core values of labour standard are respected. Decent work framework with three essential elements was adopted by this study to address the decency of the jobs created in the selected sectors and clusters.

These elements are:

- The Need for Jobs.

- Respect for core labour standards.

- Improvement in job quality.

The first element of decent work is employment because, for an individual to have a decent job, he or she must have a job. Jobs are what people want, the need for more jobs is central to the decent work framework, and full employment rightfully occupies the prime position at the forefront of the decent work effort. Job creation, therefore, depends on the information available to potential employers, and two sources of new jobs are given empirically as existing firms and new entrants. The second essential ingredient is respect for core labour standards, which aims at promoting and assuring fundamental principles and rights at work. Jobs in which these core labour standards are not respected cannot be regarded as decent. They can be characterised as indecent work: work in conditions so odious or harmful that it would be better for people not to work at all than to work in such damaging conditions (Field, 2003). The third element of decent work is improving the quality of jobs. Jobs alone are not enough, even those in which core labour standards are respected. The Director-General of the ILO states that: "The ILO is concerned not only with the creation of jobs but with the creation of jobs of acceptable quality. The quantity of employment cannot be divorced from its quality" (ILO, 2000: p. 4).

The notion of decent work incorporates fundamental rights of workers: "All those who work have rights at work" (ILO, 1999). The basic rights related to freedom of association, non-discrimination in work, and the absence of forced labour and child labour in abusive conditions. Over the years, ILO has been concerned with the four components of decent work; namely, employment, social security, workers right and social dialogue. Employment refers to work of all kinds and has both quantitative and qualitative dimensions applicable, not just to workers in the formal economy, but also to unregulated wage workers, self-employed, and informal sector worker. It also refers to adequate opportunities and remuneration for work (in cash or kind). Decent work also embraces safety at work and healthy working conditions while the social security component of decent work is intended to protect against the risk of losing income 
(ILO, 1999).

The first two components of decent work refer to opportunities, remuneration, security and conditions of work, with the last two emphasizing the social relations of workers. Social dialogue refers to the right of workers to engage in discussions with employers and authorities over matters bearing on work. The concept of decent work raises several questions, including these: Is the concept of decent work of universal validity applicable in all situations and job opportunities? Are the elements of decent work similar in nature and status? What is the nature and priority of the decent work component? In addressing the question of different components of decent work, the ILO categorises the components into two groups:

- Employment and social security.

- Workers right and social dialogue

Opportunities at work, remuneration levels, working conditions, social security are determined by the level of economic development of a nation whereas workers' rights and social dialogue are more a matter of legislation and administration. Many aspects of economic structure have implications for the attainment of decent work objectives. The most important of them relates to income per head, sectoral distribution and employment status of the labour force, government revenue and expenditure as a proportion of GDP, and the share of the public sector in productive assets and total output. Associated with some of these structural differences are differences in labour institutions that characterise the different models of decent work. The different structural and institutional features are generally interrelated but there are many exceptions (Ghai, 2002). Employment policies, therefore, need to be integrated into national development and growth strategies. These include promoting an enabling economic environment, including good governance, appropriate policy and regulatory frameworks, sound macro-economic policies, transparency, appropriate laws for property rights, adequate infrastructure, and a developed financial sector.

Productive employment is part of the concept of decent jobs, and an essential factor for poverty reduction. Productive and decent work indicators, according to ILO are:

- The growth rate of gross domestic product (GDP) per person.

- Employment-to-population-ratio (Employment rate).

- The proportion of employed people living below US\$1.25 (PPP) per day.

- The proportion of own-account and contributing family worker in total employment.

The third indicator is related to the poverty issue, which is the proportion of employed people living on less than 1.25 dollar a day (PPP). This indicator is widely used to provide information on a key aspect of the lack of decent jobs across the globe. When workers do not earn enough to escape from extreme poverty with their families, they cannot claim to have "decent jobs" (ILO, 2007). However, being a poor or indigent worker does not necessarily mean earning low wages; a worker with a good income can be found below the poverty or in- 
digence line if the household includes a large number of dependants. Also, if a worker lives in a household with daily per capita income of more than one dollar, it does not mean that he receives a decent wage. Indeed, his low income may be complemented by the income of his spouse or other members of the household, or by non-employment income such as remittances, state transfers and gifts.

\section{Methodology}

Primary data was used to address the objective of this paper. The primary data was generated from a structured questionnaire and focus group discussions. The study employed a multi-stage random sampling technique; the first stage is the selection of one state (Oyo State) from the six states in the southwest of Nigeria. Oyo state comprises of 33 local governments, 11 of which is within Ibadan metropolis. This study focuses on local governments within Ibadan metropolis in which 4 local governments were selected randomly. The beneficiaries of $\mathrm{N}$-Power across the three sectors (N-Agro, $\mathrm{N}$-Teach and $\mathrm{N}$-Health) in these four local governments were randomly selected also. The total N-Power beneficiaries in Oyo State (2016-2018) batch are 9,415 this figure stands as the total population from which the sample size was drawn using Taro Yamane (1967) sampling size formula.

The sample size for this study is 376 , randomly distributed equally (30 respondents) among beneficiaries of $\mathrm{N}$-Agro, $\mathrm{N}$-Health in all the local governments except $\mathrm{N}$-Teach with 34 respondents. The selection of $\mathrm{N}$-Power program among the job creation programs in the state is anchored on the fact that the program addresses the issue of graduate unemployment in the country and focuses on youth/graduate between the age of 18 - 35 years and covers all the 36 states of the Federation.

Two focus group discussions were held in Ibadan South West and Egbeda local governments in Ibadan, Oyo State. Each group had 30 respondents; 15 males and 15 females. The respondents were beneficiaries of N-Power $(\mathrm{N}-\mathrm{Teach}$, $\mathrm{N}$-Agro and $\mathrm{N}$-Health). The questionnaires and focus group discussion centre on the four dimensions of decent work according to ILO standard, which is: employment generations, social security, right at work and social dialogue. Other questions focus on the benefits of the programme to the beneficiaries and the worth of the stipends in terms of poverty threshold line. Descriptive and content analysis were used to analyse the information.

\section{Discussions and Results}

In job creation the issue of quality and quantity of jobs created is very important, therefore, maximizing a combination of the quantity and quality of work is like maximizing the utility arising from a person's access to goods and leisure to move the frontier further into the positive quadrant which provides inter-temporal considerations about what is said concerning decent work at a different point in 
time. The framework of decent jobs explains three essential elements; the need for jobs, respect for core labour standard and improvement in job quality. Job creation in any economy theoretically and empirically is to address the issue of unemployment/underemployment. However, the issues of right at work, the security of workers and the ability to dialogue with the management is very critical in establishing decent jobs in a nation or organization. Good remunerations of workers and benefits are part of the indicator established in the literature that drives productivity and decent work.

The distribution of N-power beneficiaries by sector of operation and local governments in Oyo State stood as 25 per cent and about 33 per cent respectively (Table 1). Although the N-power program has an age limit of 18 - 35 years and strictly for graduate, 23 per cent of the N-power beneficiaries fall within the age of 36 - 45 years which is an outlier and reflects the level of unemployment/underemployment by age in the state. Also, about 36 per cent of $\mathrm{N}$-power beneficiaries possess a Bachelor's degree, followed by Higher National Diploma and Master degree holders with 28.1 and 16.9 per cent respectively. If a graduate with Master degree certificate can be part of N-power beneficiaries with 30,000 naira take home per month, it shows the level of underemployment that is in the country and Oyo State in particular.

\subsection{Employment Generation/Need for Job}

Findings from this study show that the N-power scheme has created jobs for its beneficiaries. A good number of respondents were unemployed before their absorption into the N-power scheme as shown in Table 2. They described the conditions they lived in before their absorption into the scheme as depressing. Most of them stated that, although the stipend was not enough to meet their basic needs, it stopped them from being overly dependent on their parents. Also, some were underemployed because, in their previous work, they were underutilized and underpaid.

According to a respondent:

Table 1. Socio-demographic characteristics of respondents.

\begin{tabular}{cccccc}
\hline Local govt Area & Respondent (\%) & Marital Status & Respondent (\%) & Educational Qualification & Respondent (\%) \\
\hline Akinyele & 24.9 & Single & 36.3 & Ordinary National Diploma & 7.0 \\
Egbeda & 24.9 & Married & 63.1 & Higher National Diploma & 28.1 \\
Ibadan North & 25.2 & Divorced & 0.3 & NCE & 12.4 \\
Ibadan South East & 24.9 & Widow & 0.3 & Bachelor Degree & 35.7 \\
Sector & Respondent (\%) & Age & Respondent (\%) & Master Degree & 16.9 \\
Agric Sector & 33. & $15-25 \mathrm{yrs}$ & 5.1 & & \\
Teaching & 34 & $26-35 \mathrm{yrs}$ & 71.9 & & \\
Health & 33. & $36-45 \mathrm{yrs}$ & 23 & & \\
\hline
\end{tabular}

Source: NISER 2019 Job creation fieldwork 
Table 2. The employment situation of beneficiaries before N-power program by sector.

\begin{tabular}{ccccc}
\hline $\begin{array}{l}\text { What the respondents were } \\
\text { doing before N-Power Job }\end{array}$ & \multicolumn{4}{l}{ Agric Sector (\%) } \\
\hline Employed & 4.2 & 12.3 & 7.7 & 8.1 \\
Unemployed & 78.8 & 64.8 & 80.3 & 74.5 \\
Underemployed & 16.9 & 23.0 & 12.0 & 17.4 \\
Total & 100 & 100 & 100 & 100 \\
\hline
\end{tabular}

NISER 2019 Job creation fieldwork.

There's been an overall improvement in our lives since we started the $N$-power program. The training and networking opportunities have made us better off. We also no longer have to depend on our parents completely to survive. We now have some money to take care of ourselves.

FGD/FEMALE/N-AGRO BENEFICIARY/IBADAN SOUTH WEST/2019.

Another respondent noted:

I think that we are better with the $N$-AGRO program than we were before it. Now we have a place to go to every day instead of sitting at home idle. We are also given a stipend at the end of the month. We also gain a lot of knowledge from this program.

FGD/MALE/N-AGRO BENEFICIARY/IBADAN SOUTHWEST/2019.

In another's view:

The N-AGRO has given me more experience in Agriculture. I was a farmer on my own before this program. The business was not buoyant and I was not well equipped with knowledge for the business. Now I have a lot more knowledge about handling agricultural related issues better.

FGD/FEMALE/N-AGRO BENEFICIARY/EGBEDA/2019

\subsection{Social Security}

Another major element of decent jobs, according to the International Labour Organisation, is job security. The researcher sought to investigate how to secure the jobs created by N-power are. Generally, findings from the respondents indicated that, although jobs have been created, the jobs are not secure. None of these jobs is pensionable; nor are they covered by health insurance. There is also no concrete assurance of job continuity after the two-year scheme. In any organization, the employer always provides certain benefits to their employee in other to secure their jobs and make them comfortable to perform their duties for maximum productivity. This study considers four of these policies, which are health, pension, insurance and housing. Table 3 shows that in all the sectors where $\mathrm{N}$-power program was mounted (N-health, N-Agro, N-teach) almost all beneficiaries, 97 per cent are not involved in any social policy.

A respondent noted:

There is no pension scheme for the N-AGRO beneficiaries. Although they formed a group to protect themselves, it is not recognized by the authorities. 
Table 3. Security of N-power jobs in Oyo state.

\begin{tabular}{cccccc}
\hline \multirow{2}{*}{$\begin{array}{c}\text { Whether the respondent was involved } \\
\text { in any social policy in the office }\end{array}$} & \multicolumn{3}{c}{ Sector } & \multirow{2}{*}{ Total } \\
\cline { 3 - 5 } Y & No. & 1 & 3 & 8 & 12 \\
\hline \multirow{2}{*}{ Yes } & \% Share & $0.9 \%$ & $2.5 \%$ & $7.0 \%$ & $3.4 \%$ \\
& No. & 114 & 115 & 107 & 336 \\
No & \% Share & $99.1 \%$ & $97.5 \%$ & $93.0 \%$ & $96.6 \%$ \\
& No. & 115 & 118 & 115 & 348 \\
\multirow{2}{*}{ Total } & \% Share & $100.0 \%$ & $100.0 \%$ & $100.0 \%$ & $100.0 \%$ \\
\hline
\end{tabular}

NISER 2019 Job creation fieldwork.

This is because they are not recognized as staff of the government; they are more or less seen as contract staff. This is the situation with them.

KII/MALE/N-POWER DIRECTOR/EGBEDA/2019

Another respondent declares:

There is no union, we have no job security, there is even no health insurance for us. When we are sick, we have to treat ourselves from the little stipend being given to us. We are treated like temporary staff.

\section{FGD/FEMALE/N-TEACH BENEFICIARY/IBADAN SOUTHWEST/2019}

According to another respondent:

There are no shock absorbers for us, although we are exposed to a lot of risks on the job. If we travel and anything happens to us, we have been told that we are on our own. Even if we get involved in accidents in carrying out our duties there are no structures put in place to take care of that. We are supposed to cater for that from our stipend, which is very small.

FGD/FEMALE/N-AGRO BENEFICIARY/IBADAN SOUTHWEST/2019

Another element in any employment opportunity or job creation when considering decency of job is hazards in discharging responsibility. The study investigates who bears the cost of hazards incurred at work, the result in Table 4 shows that on the average and across all sectors 69 per cent of beneficiaries of $\mathrm{N}$-power job or their families bear the cost of any hazards incurred while about 19 per cent said both organization and beneficiaries partly bear the cost of the hazard.

The sharing of the cost of hazards in any organization will depend on the level of risk that is involved in the Job. Health sector involves a lot of risk especially for health workers, that is why the government have to provide a covering for the people in form of insurance that will cover any hazard incurred at work. 37 per cent of beneficiaries of $\mathrm{N}$-health indicated that organization share part of the cost of hazard compared to N-Teach and N-Agro with 12 and 6 per cent respectively.

\subsection{Right at Work}

The International labour organization stipulated a minimum of 8 hours as the 
Table 4. Who bears the beneficiaries cost of hazards?

\begin{tabular}{ccccc}
\hline Who bears the cost of hazard? & Agric Sector (\%) & Teaching (\%) & Health (\%) & Total (\%) \\
\hline Fully organisation & 13.2 & 11.0 & 12.1 & 12.1 \\
Partly Organisation & 5.5 & 12.0 & 37.4 & 18.6 \\
Self/Family & 81.3 & 77.0 & 50.5 & 69.3 \\
Total & 100 & 100 & 100 & 100 \\
\hline
\end{tabular}

NISER 2019 Job creation fieldwork.

number of hours that every employee must work per day for a job to be term decent in any country.

Table 5 shows the number of hours the beneficiaries of $\mathrm{N}$-power worked in the state. Over 70 per cent of the beneficiaries of N-Agro and N-Health worked for 8 hours per day while 53 per cent of beneficiaries of $\mathrm{N}$-teach worked for 8 hours, about 47 per cent worked for 6 hours. The implication of this is that jobs created through N-power especially N-Agro and N-Health are decent in terms of the hours of work per day. The peculiarity of the teaching profession is what makes almost half of the beneficiaries of N-teach worked for 6 hours, this hour is peculiar to teaching job ( $8 \mathrm{am}-2 \mathrm{pm})$ in Nigeria.

Another element of the decent job is the ability of the employee to dialogue with the employer on issues about their employment as it affects productivity and welfare; this according to ILO is categorized under social dialogue. This study explains the ability of beneficiaries of $\mathrm{N}$-power job to dialogue by looking at their involvement in a trade union.

The beneficiaries of $\mathrm{N}$-power jobs across the three sectors under consideration are not involved in any trade or labour union as shown in Table 6. The reason for this is that jobs created under N-power are not permanent jobs, hence the beneficiaries of this program cannot express themselves as a group concerning their agitations, therefore they cannot claim the full right of an employee in any sector they are posted to, violating the decent work framework or agreement of ILO.

This is the view of another respondent:

We are treated very differently from the state government workers. The state workers have access to a motorbike with fuelling to help their mobility when they are asked to work outside the office. We don't have access to that at all. We have to take it out from the stipend we get.

\section{FGD/MALE/N-AGRO BENEFICIARY/EGBEDA/2019.}

For jobs to be decent, the income earned must be above the poverty line, which is above $\$ 1.95$ per day. It must also be able to move the worker and their families out of extreme poverty. Although the stipend given to N-power beneficiaries is above that (about $\$ 2.78$ ) per day, it is less than the new poverty threshold of $\$ 3.2$ announced by the World Bank for Nigeria. Most beneficiaries lament that this stipend is not enough for them to live decently. They declare that it is not enough to meet their basic needs or their families'. The study also found 
Table 5. Number of hours worked per day.

\begin{tabular}{ccccc}
\hline Number of hours worked per day & Agric Sector (\%) & Teaching (\%) & Health (\%) & Total (\%) \\
\hline 4 hours & 1.8 & 0.0 & $0.0 \%$ & 0.6 \\
8 hours & 86.2 & 53.0 & $74.8 \%$ & 71 \\
12 hours & 3.7 & 0.0 & $4.3 \%$ & 2.6 \\
6 hours & 8.3 & 47.0 & $20.9 \%$ & 25.8 \\
Total & 100 & 100 & 100 & 100 \\
\hline
\end{tabular}

NISER 2019 Job creation fieldwork.

Table 6. Involvement of N-power beneficiaries in trade/Labour Union.

\begin{tabular}{|c|c|c|c|c|}
\hline $\begin{array}{l}\text { Beneficiaries involvement in } \\
\text { Trade/Labour Union }\end{array}$ & Agric Sector & Teaching & Health & Total \\
\hline Yes & 0.8 & 0.8 & 0.9 & 0.8 \\
\hline No & 99.2 & 99.2 & 99.1 & 99.2 \\
\hline \multirow{2}{*}{ Total } & 118 & 122 & 116 & 356 \\
\hline & 100 & 100 & 100 & 100 \\
\hline
\end{tabular}

NISER 2019 Job creation fieldwork.

that most beneficiaries support this stipend with other income-generating activities apart from N-Power job. They, therefore, would prefer the stipend to be increased.

Table 7 reveals that on the average over 50 per cent of the beneficiaries of $\mathrm{N}$-power indicated that their stipend/income is not less than $\$ 1.9$ per day, the opinion of all of them is that the money cannot meet their basic needs hence it should be increased.

For a respondent:

The stipend is grossly inadequate. It does not even cover my daily transportation from my house to my place of assignment. It does not meet my needs. It isn't enough to keep up with the daily standard of living and necessities of life.

FGD/MALE/N-TEACH BENEFICIARY/IBADAN SOUTHWEST/2019

In another's view:

The money is not enough for feeding at all. It cannot feed me and my family completely for a month. Feeding is basic, not to talk about accommodation. The money cannot secure accommodation for us at all. It is just too small and should be reviewed.

FGD/FEMALE/N-HEALTH BENEFICIARY/EGBEDA/2019

However, in terms of benefits, almost all of them said they have gained one thing or the other from $\mathrm{N}$-power especially capacity building through knowledge sharing and the i-pad given to them along with exposure and networking.

\section{Conclusions and Policy Recommendations}

Based on the above analysis, the study concluded that $\mathrm{N}$-power programme 
Table 7. Comparison of $\mathrm{N}$-power beneficiaries income with poverty line (\$1.90).

\begin{tabular}{ccccc}
\hline $\begin{array}{c}\text { Are Beneficiaries income/stipend } \\
\text { per day less than } \mathbf{\$ 1 . 9 0}\end{array}$ & Agric Sector & Teaching & Health & Total \\
\hline Yes & 35.8 & 45.9 & 31.1 & 47.1 \\
No & 64.2 & 54.1 & 68.9 & 52.9 \\
Total & 100.0 & 100.0 & 100.0 & 100.0 \\
\hline
\end{tabular}

NISER 2019 Job creation fieldwork.

addresses the issue of employment creation, specifically graduate unemployment in Nigeria. Although it is targeted at unemployed graduates, the study shows that majority of the beneficiaries were underemployed before the N-power job. However, due to lack of job security, right at work and unionism that can agitate for the right and welfare of the beneficiaries, jobs created through this N-Power programme, using N-Agro, N-Teach and $\mathrm{N}-\mathrm{Health}$, as a case study, cannot be denoted as decent. The study, therefore, recommends that the conditions of engaging graduates should be reviewed in terms of salary structure and period of engagement. Towards this, there could be the inclusion of some basic rights at work during their engagement and the tenure should be increased from two to three years with the option of engaging some of the beneficiaries as full-term staff at the Federal and State level based on specific criteria that the beneficiaries will meet. Start-up capital/quality equipment should be given to those who prefer to be on their own as a young entrepreneur.

It also recommends that an effective mentoring network for pre- and post-N-power be developed. Beneficiaries should be linked with mid/top-level career professionals to ensure that they receive adequate guidance in their chosen career paths. The monitoring and evaluation strand of N-POWER also needs significant improvement. Impact assessment studies are recommended to understand how effective the program is. Social Protection for the beneficiaries of $\mathrm{N}$-power should also be developed and taken up, to ensure that their vulnerabilities are addressed.

\section{Conflicts of Interest}

The author declares no conflicts of interest regarding the publication of this paper.

\section{References}

Adebayo, A., \& Ogunrinola, I. O. (2006). Contemporary Dimensions of Unemployment Problem in Nigeria: A Special Challenge under the National Economic Empowerment and Development Strategy. Abuja: The Nigerian Economic Society.

Anker, R., Chernyshev, I., Egger, P., Mehran, F., \& Ritter, J. A. (2003). Measuring Decent Work with Statistical Indicators. International Labour Review, 142, 147-178. https://doi.org/10.1111/j.1564-913X.2003.tb00257.x

Ayyagari, M., Demirguc-Kunt, A., \& Maksimovic, V. (2011). Small vs. Young Firms across the World: Contribution to Employment, Job Creation, and Growth. Policy Re- 
search Working Paper 5631, Washington DC: The World Bank. https://doi.org/10.1596/1813-9450-5631

Braganza, A., Chen, W., Canhoto, A., \& Sap, S. (2020). Productive Employment and Decent Work: The Impact of AI Adoption on Psychological Contracts, Job Engagement and Employee Trust. Journal of Business Research.

https://doi.org/10.1016/j.jbusres.2020.08.018

Brixiova, Z., Kangoye, T., \& Yogo, T. U. (2020). Access to Finance among Small and Medium-Sized Enterprises and Job Creation in Africa. Structural Change and Economic Dynamics, 55, 177-189. https://doi.org/10.1016/j.strueco.2020.08.008

Chen, S. C., Jiang, W., \& Ma, Y. (2020). Decent Work in a Transition Economy: An Empirical Study of Employees in China. Technological Forecasting and Social Change, 153, Article ID: 119947. https://doi.org/10.1016/j.techfore.2020.119947

Coulibaly, A., \& Yogo, U. T. (2020). The Path to Shared Prosperity: Leveraging Financial Services Outreach to Create Decent Jobs in Developing Countries. Economic Modelling, 87, 131-147. https://doi.org/10.1016/j.econmod.2019.07.013

Duffy, R. D., Kim, H. J., Gensmer, N. P., Raque-Bogdan, T. L., Douglass, R. P., England, J. W., \& Buyukgoze-Kavas, A. (2019). Linking Decent Work with Physical and Mental Health: A Psychology of Working Perspective. Journal of Vocational Behavior, 112, 384-395. https://doi.org/10.1016/j.jvb.2019.05.002

Fajana, S. (2010). Decent Work Deficits in Nigeria: A Constituents' Consensus. IIRA Conference, Lagos.

Fine, D., Van Wamelen, A., Lund, S., Cabral, A., Taoufiki, M., Dörr, N., Leke, A., Roxburgh, C., Schubert, J., \& Cook, P. (2012). Africa at Work: Job Creation and Inclusive Growth. United Kingdom: McKinsey Global Institute, McKinsey \& Company.

Fields, G, S. (2003) Decent Work and Development Policies. International Labour Review, 142, 239-262. http://digitalcommons.ilr.cornell.edu/article/261/

Ghai, D. (2005). Decent Work: Universality and Diversity. ILO Discussion Paper Series DP/159/2005, Education and Outreach Programme.

Ghai, D. (2002). Decent Work: Concepts, Models and Indicators. ILO Discussion Paper Series DP/139/2002, Education and Outreach Programme. https://doi.org/10.2139/ssrn.366061

Hoeven, R. V. D. (2012). Development Aid and Employment. UNU-WIDER Working Paper No. 2012/107, United Nations University World Institute for Development Economics Research.

Haji, S. H. H. (2007). The Youth Employment in East Africa: An Integrated Labour Market Perspective. African Integration Review, 1, 1-24.

International Labour Organization (2007). The Informal Economy and Decent Work. KeyConceptualIssues. https://www.ilo.org/global/lang--en/index.htm

ILO International Labour Organization (2009a). Guide to the New Millennium Development Goals Employment Indicators Including the Full Set of Decent Work Indicators. Geneva: International Labour Office.

ILO International Labour Organization (2009b). Recovering from the Crisis: A Global Jobs Pact. International Labour Conference Ninety-Eighth Session, Geneva. https://www.ilo.org/global/lang--en/index.htm

ILO International Labour Organization (2012). Decent Work Indicators in Africa: A First Assessment Based on National Sources. Geneva: International Labour Office.

International Labour Organisation (2013). Global Employment Trends 2013: Recovering from a Second Jobs Dip. Geneva: International Labour Office. 
ILO (1999). Report of the Director-General: Decent Work. International Labour Conference, 87 th Session, Geneva.

https://www.ilo.org/global/lang--en/index.htm

ILO (2000). Employment-Intensive Growth in the Context of Globalization. Speech by the Director-General of the ILO at a Public Meeting on the Social Summit+5, Organized by the Swiss Agency for Development and Cooperation (SDC) in Bern.

Kareem, R. O. (2015). Employment Level and Economic Growth of Nigeria. Journal of Sustainable Development Studies, 8, 53-70.

Lawrence, R. J., Paredes Gil, M., Flückiger, Y., Lambert, C., \& Werna, E. (2008). Promoting Decent Work in the Construction Sector: The Role of Local Authorities. Habitat International, 32, 160-171. https://doi.org/10.1016/j.habitatint.2007.08.012

National Bureau of Statistics (2017). Labour Force Statistics. Abuja.

Oladeji, S. I. (1994). Absorption of Educated Manpower into Nigeria's Informal Sector. National Manpower Board.

Omotor, D. G., \& Gbosi, A. N. (2006). The Dynamics of Productivity and Unemployment Nexus: Implications for Employment Generation in Nigeria. In NES, Employment Generation in Nigeria (pp. 177-197). Ibadan: Nigerian Economic Society.

Paredes, G. M., Lawrence, R., Flückiger, Y., Lambert, C., Mbiba, B., Wells, J., \& Werna, E. (2007). Promoting Decent Work in Construction and Related Services: The Key Role of Local Authorities. Final Report of a Research Project of the University of Geneva and ILO's Sectoral Activities Department, Funded by the Geneva International Academic Network.

Szirmai, A., Gebreeyesus, M., Guadagno, F., \& Verspagen, B. (2013). Promoting Productive Employment in Sub-Saharan Africa. A Review of the Literature. UNU-MERIT Working Papers, No. 062, Maastricht: Maastricht University.

Thore, S., \& Tarverdyan, R. (2009). Using Data Envelopment Analysis to Quantify ILO Objectives and Identify Policies Conducive to Decent Work in a Globalizing World. Socio-Economic Planning Sciences, 43, 151-164. https://doi.org/10.1016/j.seps.2008.06.001

Todaro, M. P. (1980). Economic Development in the Third World. New York: Longman Publishing.

Yamane, T. (1967). Statistics: An Introductory Analysis (2nd ed.). New York: Harper and Row. 